\title{
Inhibition of brain $\left[{ }^{3} \mathrm{H}\right]$ cimetidine binding by improgan-like antinociceptive drugs
}

\author{
Rebecca Stadela ${ }^{\mathrm{a}}$, Amanda B. Carpentera ${ }^{\mathrm{a}}$, Julia W. Nalwalk ${ }^{\mathrm{a}}$, Iwan J.P. de Esch $^{\mathrm{b}}$, Elwin \\ Janssen $^{\mathrm{b}}$, and Lindsay B. Hough ${ }^{\mathrm{a}}$ \\ ${ }^{a}$ Center for Neuropharmacology and Neuroscience, Albany Medical College, Albany, NY, USA ${ }^{b}$ \\ Leiden/Amsterdam Center for Drug Research, Vrije University, Amsterdam, The Netherlands
}

\begin{abstract}
$\left[{ }^{3} \mathrm{H}\right]$ Cimetidine, a radiolabeled histamine $\mathrm{H}_{2}$ receptor antagonist, binds with high affinity to an unknown hemoprotein in the brain which is not the histamine $\mathrm{H}_{2}$ receptor. Improgan, a close chemical congener of cimetidine, is a highly effective pain-relieving drug following CNS administration, yet its mechanism of action remains unknown. To test the hypothesis that the $\left[{ }^{3} \mathrm{H}\right]$ cimetidine-binding site is the improgan antinociceptive target, improgan, cimetidine, and 8 other chemical congeners were studied as potential inhibitors of $\left[{ }^{3} \mathrm{H}\right]$ cimetidine binding in membrane fractions from the rat brain. All compounds produced a concentration-dependent inhibition of $\left[{ }^{3} \mathrm{H}\right]$ cimetidine binding over a 500-fold range of potencies $\left(\mathrm{K}_{\mathrm{i}}\right.$ values were 14.5 to $\left.>8,000 \mathrm{nM}\right)$. However, antinociceptive potencies in rats did not significantly correlate with $\left[{ }^{3} \mathrm{H}\right]$ cimetidine-binding affinities $(\mathrm{r}=0.018, \mathrm{p}$ $=0.97, \mathrm{n}=10$ ). These results suggest that the $\left[{ }^{3} \mathrm{H}\right]$ cimetidine-binding site is not the analgesic target for improgan-like drugs.
\end{abstract}

\section{Introduction}

The histamine $\mathrm{H}_{2}$ receptor antagonist cimetidine exhibits high affinity, specific binding to a brain protein which is not the histamine $\mathrm{H}_{2}$ receptor, but the identity and significance of this binding site have not been determined (Warrander et al., 1983; Smith et al., 1980; Burkard, 1978). The nature of the $\left[{ }^{3} \mathrm{H}\right]$ cimetidine-binding site is of considerable interest due to the nonhistamine $\mathrm{H}_{2}$ receptor-mediated actions of cimetidine, which include antinociception (Netti et al., 1984; Hough et al., 1997) and neurotoxicity (Shimokawa et al., 1996; Amabeoku and Chikuni, 1993; Edmonds et al., 1979). Recently, the $\left[{ }^{3} \mathrm{H}\right]$ cimetidine-binding site was pharmacologically characterized in detail as a heme-containing protein, possibly a member of the cytochrome P450 superfamily (Stadel et al., 2008).

Improgan (Table 1) is a chemical congener of cimetidine that shares cimetidine's antinociceptive properties following intracerebroventricular administration, but lacks affinity for the histamine $\mathrm{H}_{2}$ receptor (Li et al., 1996). Improgan produces antinociception in several pain models, suggesting a favorable pre-clinical profile (Li et al., 1997;Bannoura et al., 1998). Evaluation of over 110 possible targets, including various ion channels and G protein-

Corresponding Author: Lindsay B. Hough, Ph.D., Center for Neuropharmacology and Neuroscience, Albany Medical College MC-136, 47 New Scotland Ave, Albany, NY 12208 USA, Phone: 518-262-5786, Fax: 518-262-5799, houghl@ mail.amc.edu.

Publisher's Disclaimer: This is a PDF file of an unedited manuscript that has been accepted for publication. As a service to our customers we are providing this early version of the manuscript. The manuscript will undergo copyediting, typesetting, and review of the resulting proof before it is published in its final citable form. Please note that during the production process errors may be discovered which could affect the content, and all legal disclaimers that apply to the journal pertain. 
coupled receptors (Hough et al., 2000a and unpublished data), has not identified the site of improgan antinociceptive action. Improgan lacks affinity for many known antinociceptive receptors, including all known histamine (Mobarakeh et al., 2003), opioid (Hough et al., 2000b), and cannabinoid receptors (Hough et al., 2002). Improgan acts in the brain stem to stimulate descending pain-relieving mechanisms which may include supraspinal cannabinoid receptors and spinal $\alpha_{2}$ adrenergic receptors, but the drug lacks affinity for these receptors as well (Hough et al., 2002; Hough et al., 2000a). Failure to identify the antinociceptive target for improgan has prevented further clinical development.

We recently found that improgan competes with $\left[{ }^{3} \mathrm{H}\right]$ cimetidine binding in the rat brain (Hough et al., 2007). The same study reported discovery of CC12 (i.e. 4(5)-((4-iodobenzyl)

thiomethyl)-1H-imidazole), a new cimetidine congener with nanomolar affinity $\left(\mathrm{K}_{\mathrm{i}}=9.5 \mathrm{nM}\right)$ for the $\left[{ }^{3} \mathrm{H}\right]$ cimetidine-binding site. $\mathrm{CC} 12$ was also found to inhibit improgan antinociception, suggesting the possibility that the $\left[{ }^{3} \mathrm{H}\right]$ cimetidine-binding site is the molecular target for improgan-like antinociceptive drugs. In order to characterize further the pharmacological properties and potential antinociceptive relevance of the $\left[{ }^{3} \mathrm{H}\right]$ cimetidine-binding site, the effects of improgan, cimetidine and 8 additional antinociceptive congeners of improgan (Table 1) have been studied presently as inhibitors of $\left[{ }^{3} \mathrm{H}\right]$ cimetidine binding.

\section{Methods}

\subsection{Chemicals}

Unless noted otherwise, the compounds in Table 1 were synthesized as described recently (Hough et al., 2006). Improgan was synthesized as described (Mobarakeh et al., 2003).

Cimetidine and thioperamide maleate were purchased from Tocris Bioscience (Ellisville, MO). Burimamide was kindly provided by Dr. Mark Wentland (Rennselaer Polytechnic Institute, Troy, NY). CC10 was kindly provided by Dr. James Phillips (Curragh Chemistries, Cleveland, $\mathrm{OH})$. Compounds in salt form were dissolved in saline. Free base forms were dissolved in dilute $\mathrm{HCl}$, titrated to $\mathrm{pH} 5.5-6.0$ and diluted with saline.

\subsection{Synthesis of VUF6990}

1-Cyano-3-[3-(1H-imidazol-4-yl)-propyl]-2-methyl-isothiourea $(0.90 \mathrm{mmol}, 200 \mathrm{mg}$, prepared according to Hough et al., 2006) was dissolved in cyclopropylmethylamine (3 ml) and heated under microwave conditions $\left(30 \mathrm{~min}, 100^{\circ} \mathrm{C}, 150 \mathrm{~W}\right)$. Co-evaporation with chloroform yielded the crude product which was purified over silica (acetone: methanol 9:1). The resulting colorless oil was crystallized with acetone/hexane, which gave the product (base) as a white foam (isolated yield $23 \%$, purity $98 \%$ by NMR). $\delta_{(\mathrm{H})}\left(\mathrm{CD}_{3} \mathrm{OD}, 200 \mathrm{MHz}\right) 7.57(\mathrm{~s}$, $1 \mathrm{H}), 6.82(\mathrm{~s}, 1 \mathrm{H}), 3.24(\mathrm{t}, \mathrm{J}=9.0 \mathrm{~Hz}, 2 \mathrm{H}), 3.06(\mathrm{~d}, \mathrm{~J}=7.6 \mathrm{~Hz}, 2 \mathrm{H}), 2.62(\mathrm{t}, 7.1 \mathrm{~Hz}, 2 \mathrm{H}), 1.87(\mathrm{~m}$, $2 \mathrm{H}), 1.07(\mathrm{~m}, 1 \mathrm{H}), 0.67-0.13(\mathrm{~m}, 4 \mathrm{H}) ; \delta_{(\mathrm{C})}\left(\mathrm{CD}_{3} \mathrm{OD}, 200 \mathrm{MHz}\right) 3.9,11.6,24.9,30.3,42.3$, 47.4, 117.3, 120.4, 135.9, 138.1, 161.2; m/z (ESI) calculated for $\mathrm{C}_{12} \mathrm{H}_{18} \mathrm{~N}_{6}: 246.31$, found: 247.1.

\subsection{Animals}

Male Sprague-Dawley rats (250-330 g, Taconic Farms, Germantown, NY) were used for all studies. They were housed in groups of 3-4 on a 12-h light/dark cycle (lights on from 0700 to 1900) with food and water ad libitum. All animal experiments were approved by the Institutional Animal Care and Use Committee of Albany Medical College.

\subsection{Isolation of brain membrane fractions}

Homogenates were prepared as recently described (Stadel et al., 2008). Rats were euthanized with an overdose of $\mathrm{CO}_{2}$ or pentobarbital and brains were rapidly removed. In some cases 
frozen brains were purchased (Taconic Farms, Germantown, NY). Brains were homogenized (polytron) in 10 volumes of homogenate buffer (100 mM Tris-HCl, 0.5 mM EDTA, pH 7.4), and centrifuged $(26,000 \times \mathrm{g}$ for $15 \mathrm{~min})$. Pellets were resuspended in buffer with a glass-teflon homogenizer, recentrifuged, and the resulting pellets stored at $-80^{\circ} \mathrm{C}$. On the day of assay, pellets were washed in assay buffer $(100 \mathrm{mM}$ Tris- $\mathrm{HCl}, \mathrm{pH} 7.4)$, centrifuged $(26,000 \times \mathrm{g}$ for $10 \mathrm{~min}$ ), resuspended in a volume 5 times the wet weight of the original tissue, and analyzed for $\left[{ }^{3} \mathrm{H}\right]$ cimetidine-binding activity.

\subsection{Radioligand binding}

$\left[{ }^{3} \mathrm{H}\right]$ cimetidine binding experiments were performed following Smith et al. (1980) as recently described (Stadel et al., 2008). Resuspended crude membrane pellets (360-470 $\mu \mathrm{g}$ of rat brain protein) were incubated in a total volume of $0.1 \mathrm{ml}$ containing $50 \mathrm{nM}\left[{ }^{3} \mathrm{H}\right]$ cimetidine (20-25 $\mathrm{Ci} / \mathrm{mmol}$, G.E. Healthcare, Piscataway, NJ), various concentrations of competing ligand, and assay buffer for $60 \mathrm{~min}$ on ice. To evaluate non-specific binding, burimamide $(30 \mu \mathrm{M})$ or cimetidine $(10 \mu \mathrm{M})$ was added. Following incubation, samples were filtered through GF/B filters. Filters were rinsed three times with $1.5 \mathrm{ml}$ of ice-cold assay buffer, placed in $5 \mathrm{ml}$ of Ecoscint scintillation fluid, and counted in a scintillation counter. Protein content was determined using the bicinchoninic acid method (Pierce Chemical,Rockford, IL). For competition studies, percent specific binding was calculated using the following formula: [(drug - non-specific)/(total - non-specific $) \times 100]$, where drug and total indicate the amount of binding in the presence and absence of competing ligand, respectively.

\subsection{Intracerebral surgery}

Surgeries, drug treatments, and antinociceptive testing of improgan and analogs were performed as recently described (Hough et al., 2006). Briefly, rats were anesthetized with pentobarbital $(25 \mathrm{mg} / \mathrm{kg}$, i.p.), supplemented with isofluorane. Guide cannulas were stereotaxically implanted aimed toward the left lateral ventricle (-0.8 AP, 1.5 ML, and -3.3 DV, mm from bregma, Paxinos and Watson, 1986) and anchored to the skull with stainless steel screws and dental cement. Following surgery, animals were housed individually and allowed to recover for 5-7 days before testing. Each animal was used for a single experiment.

\subsection{Injections and nociceptive testing}

Subjects were tested on both the hot plate (Eddy and Leimbach, 1953) and tail flick tests (D'Amour and Smith, 1941) as recently described (Hough et al., 2006). For hot plate testing, animals were placed on a $52^{\circ} \mathrm{C}$ surface and the latency to lift or lick the hind paw was recorded. Baseline latencies were 10-15 s, with a cutoff time of $60 \mathrm{~s}$. For the tail flick test, the ventral surface of the tail ( $2-5 \mathrm{~cm}$ from the tip) was exposed to radiant heat, and the latency for tail movement recorded. The heat source was set so that baseline latencies were generally $3-4 \mathrm{~s}$ with a 15-s maximal exposure. On the test day, animals underwent a single baseline hot plate test, followed by three tail flick tests performed at one min intervals. The animals were then gently secured with a laboratory pad and the injection cannula (which extended $1 \mathrm{~mm}$ beyond the guide to penetrate the ventricle) inserted. Animals received a single intracerebroventricular injection in a volume of $5 \mu \mathrm{l}$ over delivered over a $5 \mathrm{~min}$ infusion. One min following the injection, the injection cannula was sealed approximately $2 \mathrm{~mm}$ above the juncture with the guide cannula with wire cutters. Subjects were re-tested at 5,10 and 30 min following the end of drug infusion. Cannula placement was confirmed at the end of testing by an overdose of pentobarbital sodium (100 mg/kg, i.p.) followed by intracerebroventricular injection (5 $\mu \mathrm{l})$ of India Ink, removal of the brain, and visual observation of the ink in the ventricular space. Data from animals with unsuccessful injections were excluded. Nociceptive assay results are expressed as latencies ( $\mathrm{s}$, mean $\pm \mathrm{SEM}$ ). The identity of all drug solutions was blinded to the investigator. 


\subsection{Data treatment and curve-fitting}

Binding data and nociceptive latencies were fitted to sigmoidal dose-response curves with variable slopes by use of iterative non-linear regression (GraphPad Prism 4.0, San Diego, CA). Best fits yielded $\mathrm{IC}_{50}$ values for inhibitors of binding and antinociceptive $\mathrm{ED}_{50}$ values (Figs. 1 and 2). In the binding experiments, $K_{i}$ values were calculated by use of the Cheng-Prusoff equation.

\section{Results}

Improgan, cimetidine, and seven other chemical congeners (Table 1) produced concentrationdependent inhibition of $\left[{ }^{3} \mathrm{H}\right]$ cimetidine binding, yielding $\mathrm{IC}_{50}$ values between 25.4 (VUF6914) and 1,367.4 nM (improgan, Figs. 1A-C). CC10 (a conformationally-restricted congener of improgan, Table 1) displaced $\left[{ }^{3} \mathrm{H}\right]$ cimetidine by only $18.4 \%$ at the highest concentration studied $\left(10 \mu \mathrm{M}\right.$, Fig. 1B). Extrapolation of these data suggest an $\mathrm{IC}_{50}$ value greater than 15 $\mu \mathrm{M}$ for this drug. Except for CC10, Hill coefficients for the competition curves of all drugs in Fig. 1 were between $-0.86 \pm 0.12$ and $-1.28 \pm 0.12$ (mean \pm SEM, for improgan and VUF6990, respectively).

VUF6990 produced antinociceptive activity on both the hot plate and tail flick tests at 5 and 10 min post-injection, with latencies returning toward baseline values at the $30 \mathrm{~min}$ time point (data not shown). VUF6990 antinociception was dose-dependent (Fig. 2A), with an estimated $\mathrm{ED}_{50}$ value of $86.6 \mathrm{nmol}$ (Fig. 2A). The drug produced near-maximal effects following the largest dose tested (100 nmol, Fig. 2A). Vehicle treatment did not increase nociceptive latencies above baseline values. In contrast to the effects of all other drugs in Table 1, a wide range of doses of thioperamide produced no significant antinociceptive effects on either the hot plate (Fig. 2B) or tail flick tests (not shown) at any time. Except for VUF6990 and thioperamide, the antinociceptive potencies of all other compounds in Table 1 have been previously reported.

\section{Discussion}

The low affinity of cimetidine for the histamine $\mathrm{H}_{2}$ receptor $\left(\mathrm{K}_{\mathrm{i}}=0.8 \mu \mathrm{M}\right.$, (Brimblecombe et al., 1975), and the low density of brain histamine $\mathrm{H}_{2}$ receptors (Gajtkowski et al., 1983) prevent detection of the histamine $\mathrm{H}_{2}$ receptor in brain with this radioligand. Nonetheless, $\left[{ }^{3} \mathrm{H}\right]$ cimetidine binds with high affinity to an unidentified protein in the brain (Warrander et al., 1983; Smith et al., 1980). Recently, Stadel et al. (2008) reported that cyanide (a heme inhibitor) and metyrapone (a nonselective $\mathrm{P} 450$ inhibitor) competed with brain $\left[{ }^{3} \mathrm{H}\right]$ cimetidine binding, suggesting that this site may be a $\mathrm{P} 450$ isoform. However, competition studies with 10 isoformselective inhibitors, as well as direct binding studies with 8 human and 3 rat recombinant P450 isoforms, did not identify a $\left[{ }^{3} \mathrm{H}\right]$ cimetidine-binding P450 (Stadel et al., 2008). Since approximately 89 rat and 57 human $\mathrm{P} 450$ isoforms are known (http://drnelson.utmem.edu/CytochromeP450.html), many additional isoforms require examination. Because cimetidine produces actions in animals and man that are not mediated by histamine $\mathrm{H}_{2}$ receptors (Stadel et al., 2008; Cannon et al., 2004), it is important to identify this cimetidine-binding hemoprotein, and to assess its significance.

The molecular target for improgan remains unknown (Hough et al., 2007), despite extensive in vivo (Mobarakeh et al., 2003; Hough et al., 2000b) and in vitro studies (Hough et al., 2000a). In order to characterize further the improgan target, a series of seven chemical congeners of improgan were recently synthesized and studied in vivo for their antinociceptive actions (Hough et al., 2006, Table 1). As compared with improgan, drugs with longer and shorter alkyl chain lengths exhibited higher antinociceptive potencies, with the longest (8carbon) chain (i.e. VUF6914) showing a 2.7-fold greater potency. Furthermore, conformational restriction of the side chain (as in the trans-cyclopropyl derivative $\mathrm{CC} 10$ ) had virtually no 
effect on antinociceptive activity, as compared with the unconstrained analog VUF5733 (Hough et al., 2006, Table 1). Extending these earlier results, the present studies found that replacement of the $\mathrm{N}$-methyl moiety in improgan ( $\mathrm{Z}$ in Table 1 ), with the more lipophilic $\mathrm{N}$ cyclopropylmethyl substituent in VUF6990 also increased antinociceptive potency (Table 1, Fig. 2A). These structure-activity relationships are useful tools in the search for improgan's molecular target.

Although thioperamide deviates significantly in chemical structure from the other drugs in Table 1 (e.g. it contains a thiourea $[\mathrm{C}=\mathrm{S}]$ as opposed to a cyanoguanidine $[\mathrm{C}=\mathrm{NCN}]$ ) group), this drug was included in the present study because: 1 ) other thioureas structurally similar to improgan have antinociceptive properties (Hough et al., 1997), and 2) thioperamide has high affinity for the $\left[{ }^{3} \mathrm{H}\right]$ cimetidine binding site (Fig. 1, discussed further below). An earlier study reported that intracerebroventricular administration of $340 \mathrm{nmol}$ of thioperamide produced no activity on hot plate or tail flick responses in rats (Hough et al., 1997). Assuming that the improgan-like thioureas (e.g. burimamide) produce antinociception by an improgan-like mechanism, it was suggested that incorporation of either the highly constrained piperidinyl chain or the N-cyclohexyl group (or both, see Table 1) into thioperamide might account for this drug's lack of antinociceptive activity (Hough et al., 1997). The present results with even larger doses of drug (Fig. 2B) seem to confirm that thioperamide does not have pronounced antinociceptive activity.

Several earlier studies have reported that the histamine $\mathrm{H}_{3}$ receptor antagonist thioperamide has antinociceptive and/or anti-hyperalgesic properties (Oluyomi and Hart, 1991; MalmbergAiello et al., 1994; Farzin et al., 2002; Li et al., 1996; Huang et al., 2007). On the hot plate test, mild antinociceptive effects (up to $30 \%$ of maximal) were observed after either peripheral (Malmberg-Aiello et al., 1994; Farzin et al., 2002) or CNS (Li et al., 1996) administration of low to moderate doses of thioperamide. Larger doses reversed these effects, yielding U-shaped dose-response curves (Malmberg-Aiello et al., 1994; Li et al., 1996), commensurate with the results of Fig. 2B. Since blockade of CNS histamine $\mathrm{H}_{3}$ receptors releases histamine (Haas et al., 2008), and intracerebral histamine's dose-response curve on the hot plate test mimics the effects of thioperamide ( $\mathrm{Li}$ et al, 1996), these mild, biphasic effects of thioperamide are likely to result from an action at the brain $\mathrm{H}_{3}$ receptor. Because of the biphasic effects of thioperamide, the possibility that this drug's histamine $\mathrm{H}_{3}$ receptor affinity might somehow interfere with the assessment of thioperamide's improgan-like activity should be considered. This seems not to be the case, however, since improgan lacks significant affinity for the histamine $\mathrm{H}_{3}$ receptor, and improgan antinociception is readily detected in histamine $\mathrm{H}_{3}$ receptor null mice (Mobarakeh et al., 2003). These results strongly argue that thioperamide has little or no affinity at the improgan antinociceptive target.

The present results show several notable features of the structure-activity relationship for the improgan congeners at the $\left[{ }^{3} \mathrm{H}\right]$ cimetidine-binding site. For instance, the 4-methyl-n-butyl (VUF5651) and the n-butyl (VUF5420) congeners have nearly identical binding affinities $\left(\mathrm{K}_{\mathrm{i}}\right.$ values $=122.4$ and $154.2 \mathrm{nM}$, respectively, Table 1$)$, suggesting a minimal impact of the 4-methyl group on binding. The 4-fold higher affinity of cimetidine (the thioether congener, $\mathrm{K}_{\mathrm{i}}=30.6 \mathrm{nM}$ ) relative to VUF5651 (the 4-methyl-n-butyl congener) may be due to the longer side chain introduced by sulfur. This conclusion seems consistent with the negligible impact of the 4-methyl substituent (above) and with the high binding potency of the n-pentylderivative, VUF6913. The most potent ligands for $\left[{ }^{3} \mathrm{H}\right]$ cimetidine binding identified presently are the longer-chained (6 to 8- carbon) congeners of improgan. It is not known if the high potency of these ligands is strictly due to increased lipophilicity or to more defined conditions. Lipophilicity may play some role, as replacement of the $\mathrm{N}$-methyl moiety in improgan with the more lipid soluble N-cyclopropyl substituent (VUF6990) nearly doubled the binding affinity. Side chain lipophilicity alone does not seem to account for binding activity, since 
VUF5733, the 2-carbon congener, is dramatically more potent than improgan, the 3-carbon congener $\left(\mathrm{K}_{\mathrm{i}}=89 \mathrm{vs} 782 \mathrm{nM}\right.$, respectively). CC10, the 2-carbon conformationally-restricted derivative, had unexpectedly low binding activity. The trans-geometry of this compound may suggest that access to the $\left[{ }^{3} \mathrm{H}\right]$ cimetidine binding site requires a cis-geometry in the active congeners, but other interpretations are also possible.

Correlational analysis relating receptor-binding potencies to pharmacological responses is a classic approach for validating the biological relevance of a drug-binding site (Kenakin, 1997). For example, Compton et al. (1993) demonstrated significant correlations between the cannabinoid $\mathrm{CB}_{1}$-receptor binding affinities and cannabinoid-like "tetrad" effects for 29 compounds. Similar studies have validated the clinical analgesic relevance of $\mu$-opioid receptor binding assays (Wilson et al., 1975; Pert and Snyder, 1973). Presently, it was reasoned that if the $\left[{ }^{3} \mathrm{H}\right]$ cimetidine-binding site represents the improgan antinociceptive receptor, then the $\left[{ }^{3} \mathrm{H}\right]$ cimetidine-binding affinities for improgan-like congeners should correlate with their antinociceptive potencies.

Although nine of the ten compounds in Table 1 fully competed with $\left[{ }^{3} \mathrm{H}\right]$ cimetidine-binding (Fig. 1), a significant correlation between binding affinities and antinociceptive potencies was not found (Fig. 3, Pearson correlation $\mathrm{r}=0.018, \mathrm{p}=0.97, \mathrm{n}=10$ ). For example, CC10 and VUF5733 have similar antinociceptive activities (106.1 vs. $137.2 \mathrm{nmol}$, respectively, Table 1), yet display highly disparate (>90-fold) binding affinities (>8,000 vs. $89 \mathrm{nM}$, respectively, Table 1). Furthermore, as compared with improgan, more potent (VUF6914, ED50 $=81.9 \mathrm{nmol})$ and less potent (cimetidine, $\mathrm{ED}_{50}=417.3 \mathrm{nmol}$ ) antinociceptive congeners maintain low nanomolar binding affinities $\left(K_{i}=14.5\right.$ and $30.6 \mathrm{nM}$, respectively, Table 1). Finally, the lack of antinociceptive activity of very high doses of thioperamide is in striking contrast with this drug's moderately high affinity $\left(\mathrm{IC}_{50}=175.3 \mathrm{nM}\right)$ for the $\left[{ }^{3} \mathrm{H}\right]$ cimetidine binding site. Taken at face value, the absence of a significant correlation in Fig. 3 suggests that the $\left[{ }^{3} \mathrm{H}\right]$ cimetidinebinding site does not mediate the antinociceptive effects of these improgan-like compounds.

Although the present results do not confirm an antinociceptive role for $\left[{ }^{3} \mathrm{H}\right]$ cimetidine binding, neither do they completely exclude the analgesic relevance of this site. For example, if the drugs tested presently are behaving as agonists (improgan-like partial agonists may have been discovered, see Hough et al., 2006), then the absence of a correlation in Fig. 1 could be due to variations in agonist efficacy. Agonist $\mathrm{ED}_{50}$ values are known to depend upon both affinity and intrinsic efficacy (Kenakin, 1997), and notable differences in agonist intrinsic efficacies have been reported (Emmerson et al., 1996;Porreca et al., 1990; Quock et al., 1999). In order for the $\left[{ }^{3} \mathrm{H}\right]$ cimetidine-binding site to mediate the presently-studied antinociceptive activities, wide variations in intrinsic efficacies would have to exist across the drug series. However, without an in vitro functional assay for the improgan receptor, the intrinsic efficacies of the drugs in Table 1 cannot be determined. Since competitive antagonists show significant correlations between binding activity and functional antagonism (without the additional complexities of agonist efficacy [Quock et al., 1999]), the best correlational study to assess the analgesic significance of the $\left[{ }^{3} \mathrm{H}\right]$ cimetidine binding site would utilize improgan antagonists. Despite progress, an improgan receptor antagonist has not yet been definitely identified (Hough et al., 2007).

Pharmacokinetic factors such as drug metabolism and distribution can sometimes account for inconsistencies in correlations between $\mathrm{ED}_{50}$ values and binding affinities (e.g. see Pert and Snyder, 1973). However, the presently-studied compounds were administered directly into the brain lateral ventricle, circumventing both the liver and the blood brain barrier, and all were active within five minutes after administration, minimizing this potential concern. 
The possible presence of multiple $\left[{ }^{3} \mathrm{H}\right]$ cimetidine-binding proteins in the brain could have prevented accurate determinations of affinity constants for improgan analogs, thereby potentially confusing correlational results. We have recently detected $\left[{ }^{3} \mathrm{H}\right]$ cimetidine binding in rodent liver with pharmacological properties distinct from the brain $\left[{ }^{3} \mathrm{H}\right]$ cimetidine-binding site (data not shown), suggesting the possible existence of more than one binding site. However, most saturation studies with $\left[{ }^{3} \mathrm{H}\right]$ cimetidine binding in rat brain homogenates found only one site (Kendall et al., 1980; Smith et al.; 1980; Stadel et al., 2008). Furthermore, the present finding that all competing ligands of Table 1 exhibited Hill coefficients close to unity (Fig. 1) is commensurate with the existence of a single class of binding sites in the brain.

The present correlational analysis also makes the assumption that all of the compounds in Table 1 produce antinociception by the same mechanism. Although this is a reasonable assumption for such a series of close congeners, it may not pertain to all drugs in Table 1. For example, cimetidine may have an antinociceptive mechanism distinct from that of improgan (Hough et al., 2004). Further studies are required to determine the possible significance of cimetidine antinociception in the search for the improgan antinociceptive target.

\section{Acknowledgments}

This work was supported by grants (DA-03816, DA-07307) from the National Institute on Drug Abuse. We thanks K. Svokos for excellent technical assistance.

\section{References}

Amabeoku GJ, Chikuni O. Cimetidine-induced seizures in mice antagonism by some GABAergic agents. Biochem Pharmacol 1993;46:2171-2175. [PubMed: 8274150]

Bannoura MD, Nalwalk JW, Tang Y, Carlile M, Leurs R, Menge WMPB, Timmerman H, Hough LB. Absence of antinociceptive tolerance to improgan, a cimetidine analog, in rats. Brain Research 1998;814:218-221. [PubMed: 9838126]

Brimblecombe RW, Duncan WAM, Durant GJ, Ganellin CR, Parsons ME, Black JW. The pharmacology of cimetidine, a new histamine $\mathrm{H}_{2}$-receptor antagonist. British Journal of Pharmacology 1975;53:435436.

Burkard WP. Histamine $\mathrm{H}_{2}$-receptor binding with ${ }^{3} \mathrm{H}$-cimetidine in brain. Eur J Pharmacol 1978;50:449450. [PubMed: 699967]

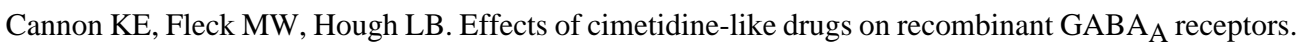
Life Sci 2004;75:2551-2558. [PubMed: 15363660]

Compton DR, Rice KC, De Costa BR, Razdan RK, Melvin LS, Johnson MR, Martin BR. Cannabinoid structure-activity relationships: correlation of receptor binding and in vivo activities. J Pharmacol Exp Ther 1993;265:218-226. [PubMed: 8474008]

Crane LA, Glick SD. Simple cannula for repeated intracerebral drug administration in rats, Pharmacol. Biochem Behav 1979;10:799-800.

D'Amour FE, Smith DL. A method for determining loss of pain sensation. J Pharmacol Exp Ther 1941;72:74-79.

Eddy NB, Leimbach D. Synthetic analgesics: II. Dithienylbutenyland dithienylbutylamines. J Pharmacol Exp Ther 1953;107:385-393. [PubMed: 13035677]

Edmonds ME, Ashford RF, Brenner MK, Saunders A. Cimetidine: does neurotoxicity occur? Report of three cases. J R Soc Med 1979;72:172-175. [PubMed: 552491]

Emmerson PJ, Clark MJ, Mansour A, Akil H, Woods JH, Medzihradsky F. Characterization of opioid agonist efficacy in a C6 glioma cell line expressing the mu opioid receptor. J Pharmacol Exp Ther 1996;278:1121-1127. [PubMed: 8819494]

Farzin D, Asghari L, Nowrouzi M. Rodent antinociception following acute treatment with different histamine receptor agonists and antagonists. Pharmacol Biochem Behav 2002;72:751-760. [PubMed: 12175473] 
Gajtkowski GA, Norris DB, Rising TJ, Wood TP. Specific binding of ${ }^{3} \mathrm{H}$-tiotidine to histamine $\mathrm{H}_{2}$ receptors in guinea pig cerebral cortex. Nature 1983;304:65-67. [PubMed: 6135157]

Haas HL, Sergeeva OA, Selbach O. Histamine in the nervous system. Physiol Rev 2008;88:1183-1241. [PubMed: 18626069]

Hough LB, de Esch I, Janssen E, Phillips J, Svokos K, Kern B, Trachler J, Abood ME, Leurs R, Nalwalk JW. Antinociceptive activity of chemical congeners of improgan: optimization of side chain length leads to the discovery of a new, potent, non-opioid analgesic. Neuropharmacology 2006;51:447-456. [PubMed: 16806300]

Hough LB, Nalwalk JW, Barnes WG, Leurs R, Menge WM, Timmerman H, Wentland M. A third life for burimamide. Discovery and characterization of a novel class of non-opioid analgesics derived from histamine antagonists. Ann N Y Acad Sci 2000a;909:25-40. [PubMed: 10911922]

Hough LB, Nalwalk JW, Li BY, Leurs R, Menge WM, Timmerman H, Carlile ME, Cioffi C, Wentland M. Novel qualitative structure-activity relationships for the antinociceptive actions of $\mathrm{H}_{2}$ antagonists, $\mathrm{H}_{3}$ antagonists and derivatives. J Pharmacol Exp Ther 1997;283:1534-1543. [PubMed: 9400031]

Hough LB, Nalwalk JW, Phillips JG, Kern B, Shan Z, Wentland MP, de Esch I, Janssen E, Barr T, Stadel R. CC12, a high-affinity ligand for $[3 \mathrm{H}]$ cimetidine binding, is an improgan antagonist. Neuropharmacology 2007;52:1244-1255. [PubMed: 17336343]

Hough LB, Nalwalk JW, Stadel R, Timmerman H, Leurs R, Paria BC, Wang X, Dey SK. Inhibition of improgan antinociception by the cannabinoid (CB)(1) antagonist N-(piperidin-1-yl)-5-(4chlorophenyl)-1-(2,4-dichlorophenyl)-4-methyl-1H-p yrazole-3-carboxamide (SR141716A): lack of obligatory role for endocannabinoids acting at $\mathrm{CB}(1)$ receptors. J Pharmacol Exp Ther 2002;303:314-322. [PubMed: 12235266]

Hough LB, Nalwalk JW, Svokos K, Leurs R, Timmermann H. Pain-relieving drugs and the brain histaminergic system: multiple analgesic mechanisms from histamine, improgan and cimetidine. Inflamm Res 2004;53:S43-S44. [PubMed: 15054611]

Hough LB, Nalwalk JW, Chen Y, Schuller A, Zhu Y, Zhang J, Menge WMPB, Leurs R, Timmerman H, Pintar JE, Arora VK. Improgan, a cimetidine analog, induces morphine-like antinociception in opioid receptor-knockout mice. Brain Research 2000b;880:102-108. [PubMed: 11032994]

Huang L, Adachi N, Nagaro T, Liu K, Arai T. Histaminergic involvement in neuropathic pain produced by partial ligation of the sciatic nerve in rats. Reg Anesth Pain Med 2007;32:124-129. [PubMed: 17350523]

Kenakin, T. Pharmacologic Analysis of Drug-Receptor Interaction. Lippincot-Raven; Philadelphia: 1997. Efficacy; p. 289-330.

Kendall DA, Ferkany JW, Enna SJ. Properties of ${ }^{3} \mathrm{H}$-cimetidine binding in rat brain membrane fractions. Life Sci 1980;26:1293-1302. [PubMed: 7382717]

Li BY, Nalwalk JW, Barker LA, Cumming P, Parsons ME, Hough LB. Characterization of the antinociceptive properties of cimetidine and a structural analog. J Pharmacol Exp Ther 1996;276:500-508. [PubMed: 8632315]

Li BY, Nalwalk JW, Finkell JM, Glick SD, Hough LB. SKF92374, a cimetidine analogue, produces mechanical and thermal antinociception in the absence of motor impairment. Analgesia 1997;3:1522.

Malmberg-Aiello P, Lamberti C, Ghelardini C, Giotti A, Bartolini A. Role of histamine in rodent antinociception. Br J Pharmacol 1994;111:1269-1279. [PubMed: 8032614]

Mobarakeh JI, Nalwalk JW, Watanabe T, Sakurada S, Hoffman M, Leurs R, Timmerman H, SilosSantiago I, Yanai K, Hough LB. Improgan antinociception does not require neuronal histamine or histamine receptors. Brain Research 2003;974:146-152. [PubMed: 12742632]

Netti C, Bossa R, Galatulas I, Sibilia V, Pecile A. Antinociceptive effect of centrally administered cimetidine and dimaprit in the rat. Pharmacology 1984;28:262-267. [PubMed: 6233621]

Oluyomi AO, Hart SL. Involvement of histamine in naloxone-resistant and naloxone- sensitive models of swim stress-induced antinociception in the mouse. Neuropharmacology 1991;30:1021-1027. [PubMed: 1922693]

Paxinos, G.; Watson, C. The Rat Brain in Stereotaxic Coordinates. Academic Press; Sydney: 1986.

Pert CB, Snyder SH. Properties of opiate-receptor binding in rat brain. Proc Natl Acad Sci USA 1973;70:2243-2247. [PubMed: 4525427] 
Porreca F, LoPresti D, Ward SJ. Opioid agonist affinity in the guinea-pig ileum and mouse vas deferens. Eur J Pharmacol 1990;179:129-139. [PubMed: 2163849]

Quock RM, Burkey TH, Varga E, Hosohata Y, Hosohata K, Cowell SM, Slate CA, Ehlert FJ, Roeske WR, Yamamura HI. The delta-opioid receptor: molecular pharmacology, signal transduction, and the determination of drug efficacy. Pharmacol Rev 1999;51:503-532. [PubMed: 10471416]

Shimokawa M, Yamamoto K, Kawakami J, Sawada Y. Neurotoxic convulsions induced by histamine H2 receptor antagonists in mice. Toxicology and Applied Pharmacology 1996;136:317-323. [PubMed: 8619239]

Smith IR, Cleverley MT, Ganellin CR, Metters KM. Binding of [3H]cimetidine to rat brain tissue. Agents Actions 1980;10:422-426. [PubMed: 6111196]

Stadel R, Yang J, Nalwalk JW, Phillips JG, Hough LB. High-affinity binding of [3H]cimetidine to a heme-containing protein in rat brain. Drug Metab Dispos 2008;36:614-621. [PubMed: 18094038]

Warrander SE, Norris DB, Rising RJ, Wood TP. ${ }^{3} \mathrm{H}$-Cimetidine and the $\mathrm{H}_{2}$-receptor. Life Sci 1983;33:1119-1126. [PubMed: 6888167]

Wilson RS, Rogers ME, Pert CB, Snyder SH. Homologous N-alkylnorketobemidones. Correlation of receptor binding with analgesic potency. J Med Chem 1975;18:240-242. [PubMed: 1133811] 


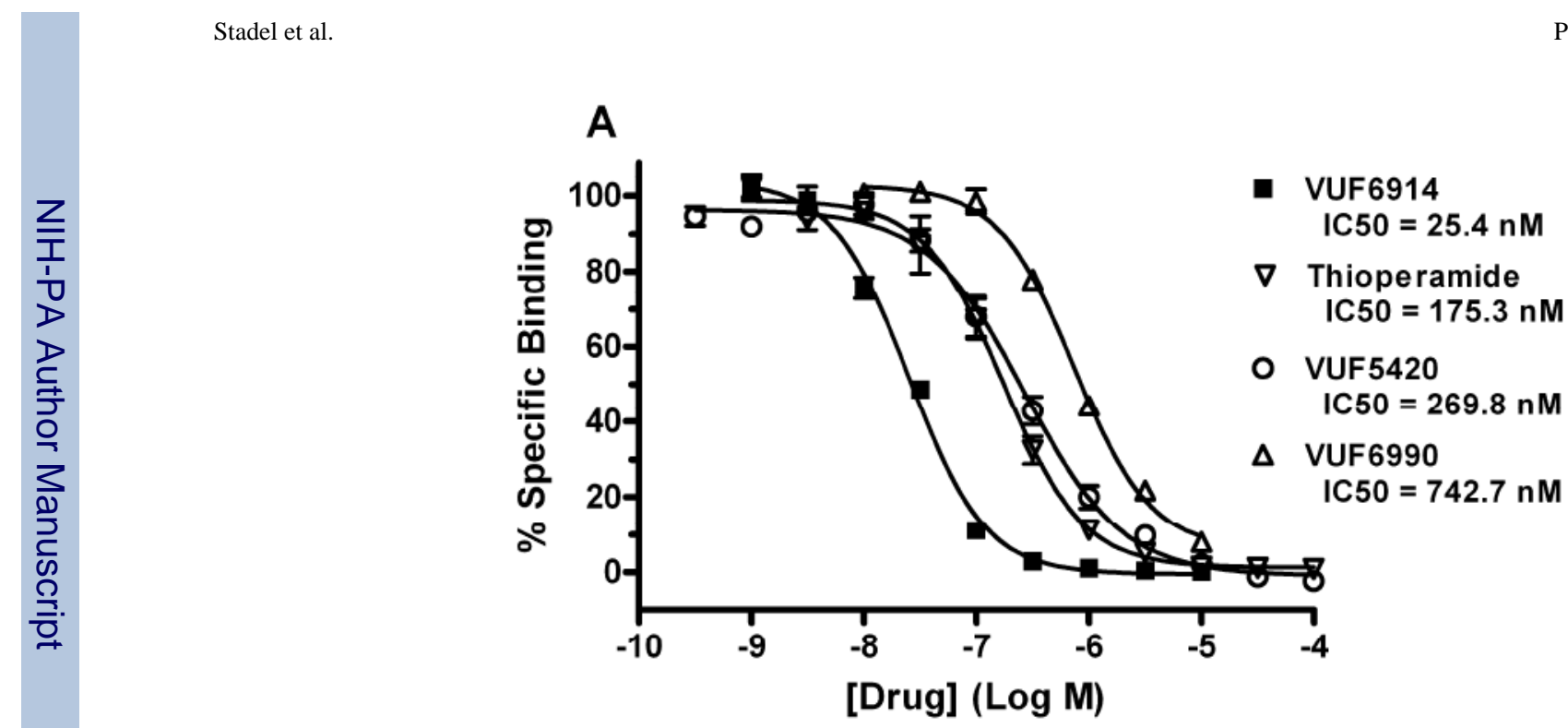



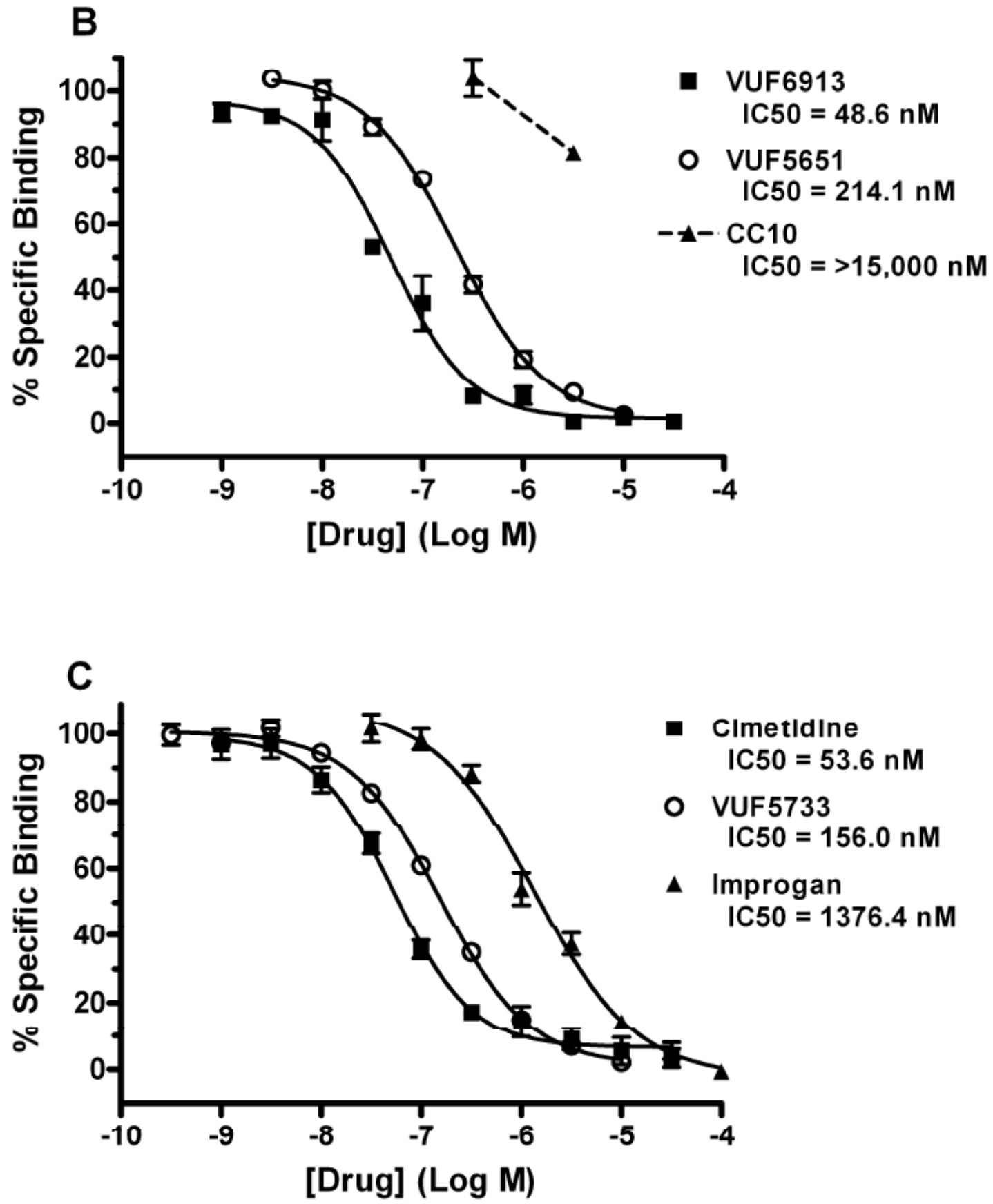

Figure 1.

Inhibition of $\left[{ }^{3} \mathrm{H}\right]$ cimetidine binding by improgan-like drugs. Whole brain crude membrane homogenates $(360-470 \mu \mathrm{g})$ were incubated in triplicate, on ice, with $50 \mathrm{nM}\left[{ }^{3} \mathrm{H}\right]$ cimetidine for 60 minutes and filtered as described. Non-specific binding was evaluated with $10 \mu \mathrm{M}$ cimetidine or $30 \mu \mathrm{M}$ burimamide. Each data point represents the mean \pm SEM of a total of 6-9 determinations, from 2-3 separate experiments. Except for $\mathrm{CC} 10$, competition curves for each drug show the best fit by non-linear regression. $\mathrm{IC}_{50}$ values are given on the right. The dotted line connects CC10 data points. Examples of mean total and non-specific binding were 6352 cpms $(0.29 \mathrm{pmol})$ and $1530 \mathrm{cpms}(0.07 \mathrm{pmol})$, respectively. Improgan data were re-drawn from Hough, et. al. (2007). 


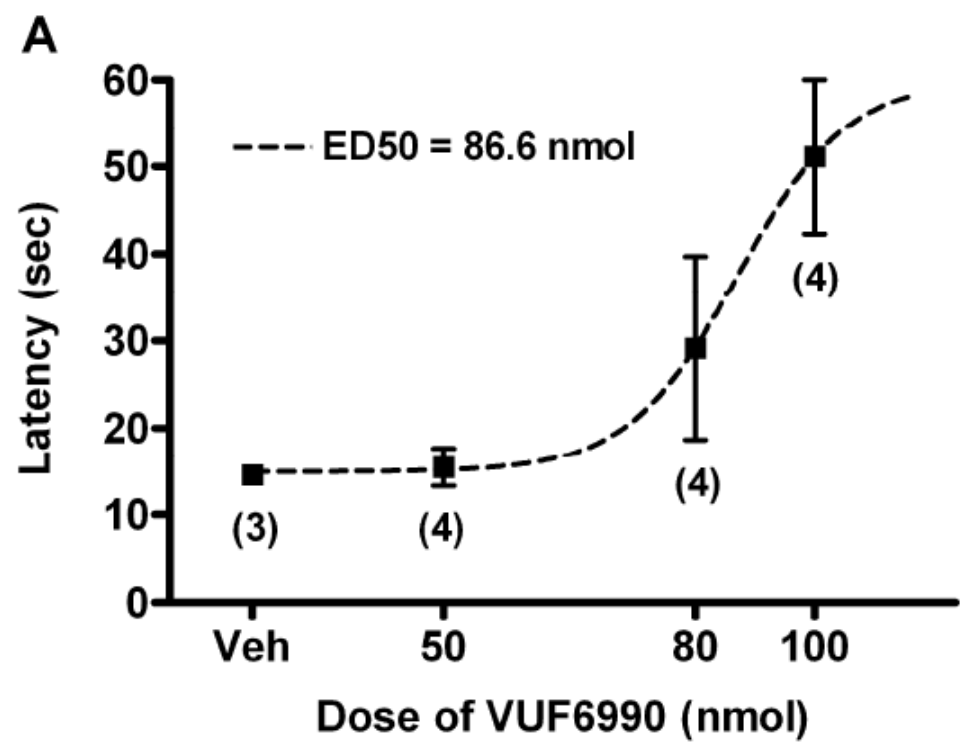

B

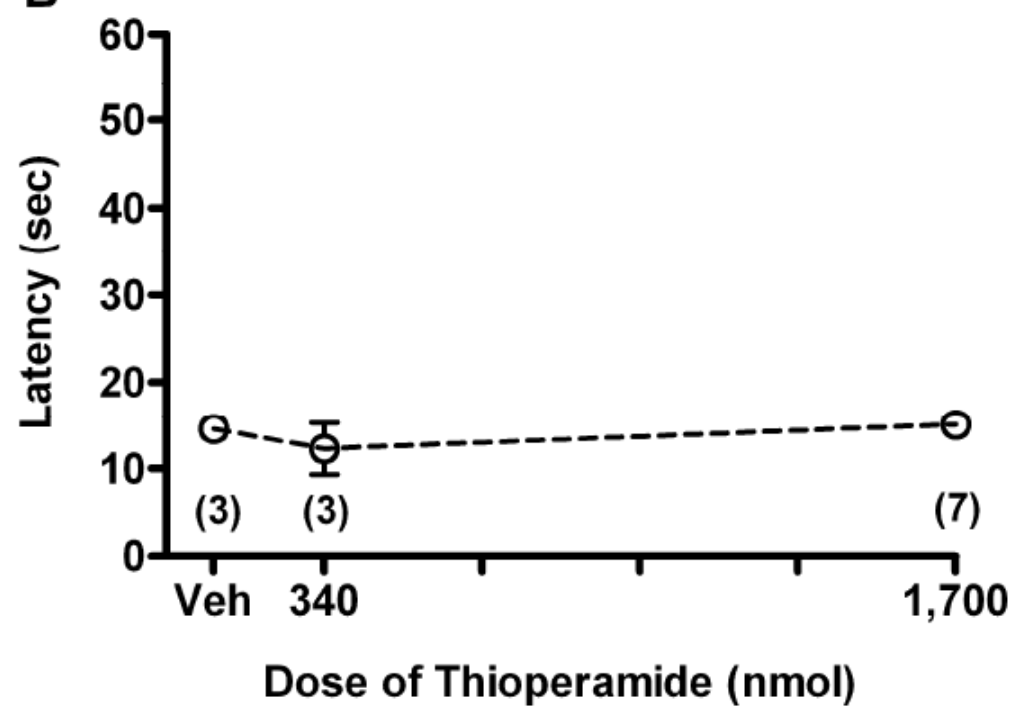

Figure 2.

Effects of VUF6990 and thioperamide on hot plate nociceptive responses. Cannulated rats were tested for baseline responses, received intracerebroventricular injections $(5 \mu \mathrm{l})$ of either VUF6990 (A, top), thioperamide (B, bottom), or saline vehicle (Veh; A, B), and were re-tested. Nociceptive responses ( $\mathrm{sec}$, ordinate, mean \pm SEM for the number of subjects in parentheses) are shown 5 min after drug administration at the doses specified (nmol, abscissa). The $\mathrm{ED}_{50}$ value for VUF6990 (obtained by non-linear regression, dashed line) is given in A. The same vehicle data are shown in $\mathrm{A}$ and $\mathrm{B}$. 


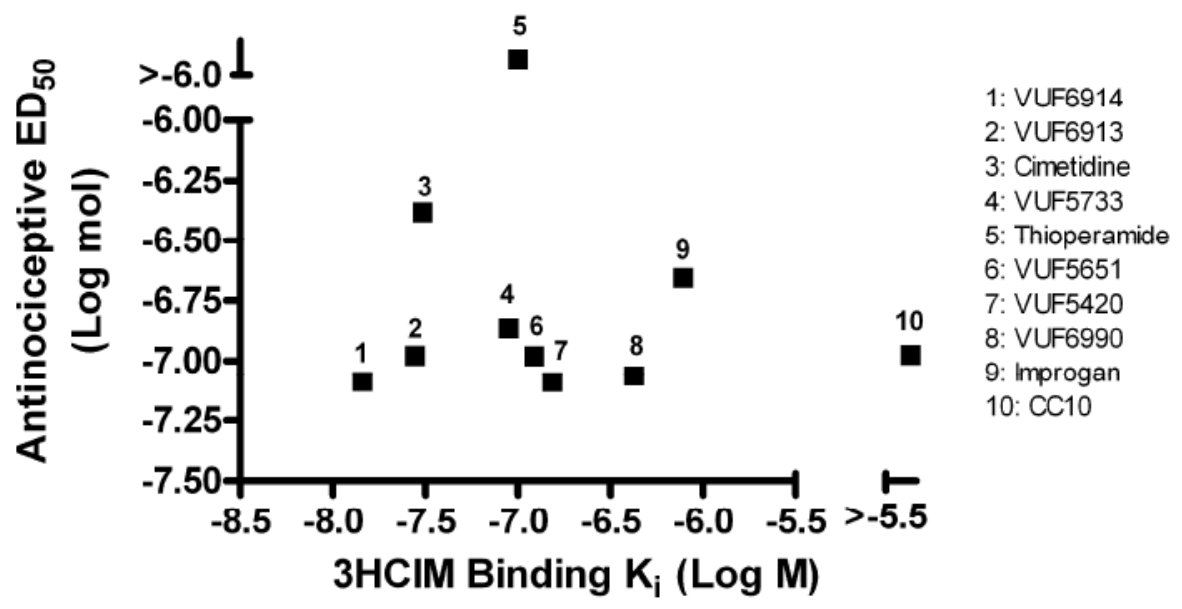

Figure 3.

Relationship between $\left[{ }^{3} \mathrm{H}\right]$ cimetidine binding affinity and antinociceptive potency for a series of improgan-like drugs. For each drug in Table 1 (identified by number on the right), the $\mathrm{K}_{\mathrm{i}}$ value for $\left[{ }^{3} \mathrm{H}\right]$ cimetidine binding $(\mathrm{M}, \log$ scale, abscissa) is plotted against antinociceptive $\mathrm{ED}_{50}$ (mol, log scale, ordinate). Values taken from Table 1. No significant correlation was found between binding and antinociceptive potencies. 


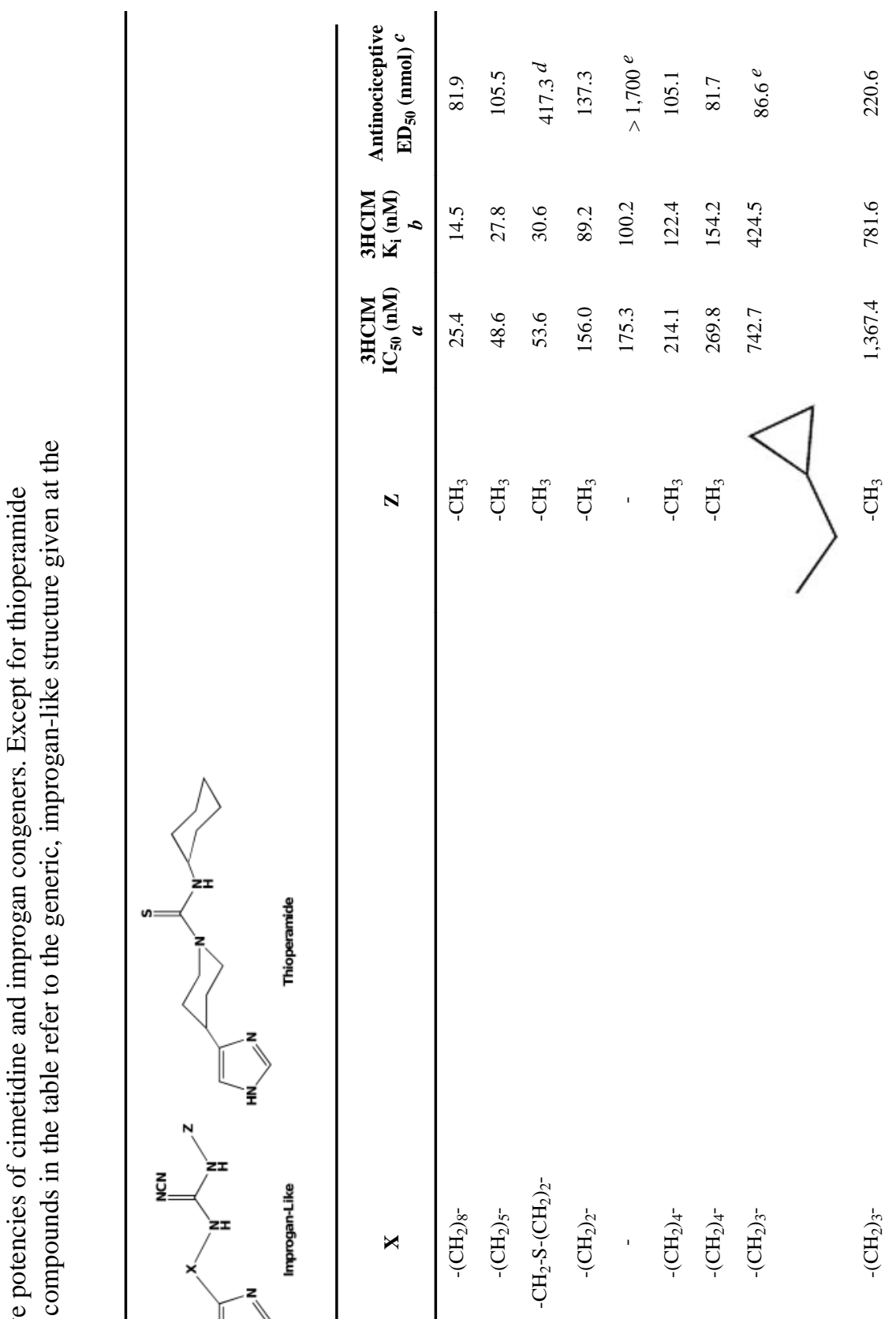

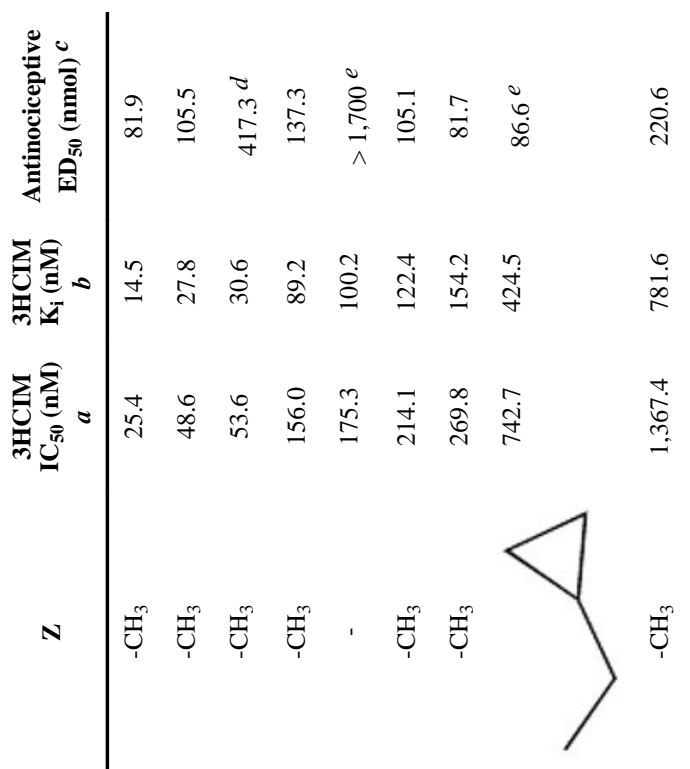


Stadel et al.
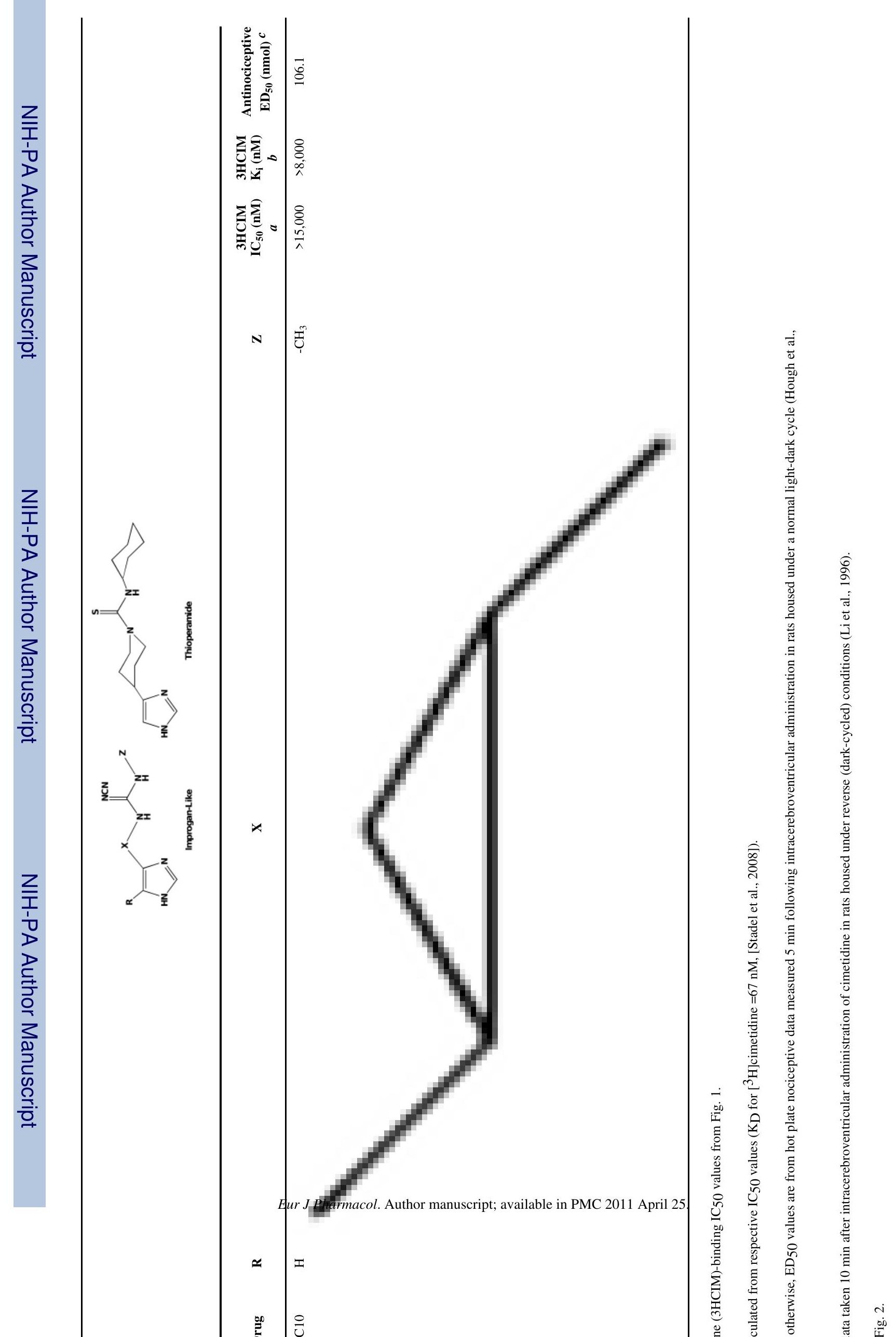